\title{
The neurology resident as teacher Evaluating and improving our role
}

\author{
David J. Gill, MD; and Samuel A. Frank, MD
}

\begin{abstract}
There is a need to improve the quality of teaching done by neurology residents because neurology residents are intimately involved in medical student education. This article reviews the available literature on techniques to improve the teaching ability of resident physicians. Eight randomized prospective studies were identified from health and education databases. The outcomes measured were student ratings of residents or objective ratings of interactions between residents and students. The skills curriculum provided a more robust response, and the objective standardized teaching examination (OSTE) provided a standardized outcome. There continues to be a need for studies specifically addressing the teaching by neurology residents and fellows.
\end{abstract}

NEUROLOGY 2004;63:1334-1338

$\mathbf{R}$ esident physicians spend up to $25 \%$ of their time teaching medical students and other residents. ${ }^{1,2}$ The American Association of Medical Colleges (AAMC) has recognized that resident teaching has an important impact on medical education. ${ }^{3}$ This is borne out by surveys that show medical students feel the teaching done by residents is important to their education. ${ }^{4}$ Within neurology, resident teaching is required as a part of residency. The neurology residency review committee of the Accreditation Council for Graduate Medical Education (ACGME) sets the standards for accreditation of neurology residencies and states: "Teaching of other residents, medical students, nurses, and other health care personnel, formally and informally, is a required aspect of the resident's education in neurology."

To improve resident teaching skills, residencies have begun to incorporate teaching programs, typically in the form of training sessions. A recent survey of family medicine, internal medicine, psychiatry, general surgery, and obstetrics/gynecology residents found that $55 \%$ of all residency programs offered instruction to its residents in teaching skills. ${ }^{6}$ Unfortunately, the published surveys do not include neurology residencies, and the rate of resident teaching programs in neurology is not known.

The AAMC, an advocacy group for medical student and resident education, and the Liaison Committee on Medical Education (LCME), the accreditation group for medical schools, advocate for improving teaching skills for residents. These organizations feel that these skills are particularly important for residents who teach "core clinical clerkships" for thirdyear medical students. ${ }^{7}$ The education subcommittee of the American Academy of Neurology has previously recommended the neurology clerkship be in the third year. ${ }^{8}$ This group feels that neurology is an important part of third-year medical education because of the prevalence of neurologic diseases that will be cared for by primary care physicians. If the AAMC and LCME feel strongly that residents who teach third-year clerks should have specific training and neurology is to be a third-year clerkship, then it follows that neurology residencies should prepare its residents to teach as well.

Despite the emphasis from authoritative groups that teaching is important, there is little published literature addressing how to improve residents' ability to teach. Many of the available articles do not use standardized outcome measures or are not prospective controlled trials. The lack of research on teaching techniques is especially evident in neurology where there are only

See also pages 1154,1331 , and 1343

From the Department of Neurology, University of Rochester, NY.

Received January 5, 2004. Accepted in final form July 8, 2004.

Address correspondence and reprint requests to Dr. David J. Gill, Neurology Resident, University of Rochester, Department of Neurology, Box 673, 601

Elmwood Ave., Rochester, NY 14642; e-mail: david_gill@urmc.rochester.edu

1334 Copyright (C) 2004 by AAN Enterprises, Inc. 
two published studies of teaching strategies in a neurology setting and neither deals with teaching improvement methods for residents. ${ }^{9,10}$ Although there is scant literature on how to improve neurology resident teaching skills, there are published guidelines on what medical students should learn from residents and attendings in neurology. These are outlined in the neurology clerkship core curriculum. ${ }^{11}$ To improve the ability of neurology residents to teach the topics deemed necessary, we endeavored to find effective methods of teaching residents to teach. This article reviews the literature on resident teaching throughout all specialties, as there are no published studies that include neurology residents. We critically evaluated studies that used high quality research techniques and outlined needs for future study within neurology.

\section{Methods}

\section{Strategy for identification of} studies

We identified trials of interventions to improve the quality of teaching done by residents of all specialties. Studies were identified by searching the National Library of Medicine's PubMed database (1966 to 2004) using the medical subject headings "internship and residency" and "medical education." The Educational Resources Information Center (ERIC) database (1966 to 2004) was searched using the terms "residency" and "teaching." In addition, the bibliography of the Web site http:// www.residentteachers.com ${ }^{12}$ was used. Several experts in the field were contacted to ensure that unreported trials were included.

\section{Inclusion/exclusion criteria}

Studies were included if they were prospective, randomized controlled trials of techniques to improve the ability of residents to teach medical students. Studies were excluded if they were not prospective, controlled, or randomized.

\section{Data extraction}

Once articles were chosen based on the inclusion criteria, the authors (D.G. and S.F.), extracted data including date of publication, study type, number of subjects, type of resident, type of intervention and control, outcome measures, and the results.

\section{Results}

The initial PubMed and ERIC search yielded 33 articles. An additional study was identified from the Web site http://www.residentteachers.com. ${ }^{12}$ After reviewing titles and abstracts, eight articles met the inclusion criteria. The remaining articles were excluded because they were observational, not randomized, or not controlled studies.

The studies are summarized in table 1 . The eight studies ${ }^{13-20}$ examined teaching methods from a variety of residencies. Only two ${ }^{16,20}$ of the studies included baseline data about the control and treatment group. With regard to interventions, five studies ${ }^{13,14,17,18,20}$ used formal skill sessions to improve resident teaching ability. These sessions varied from one half day teaching seminars to a series of 1-hour conferences. The remaining three studies $^{15,16,19}$ used direct or summarized student feedback to improve the teaching skills of residents.

For outcome measures, five of the studies ${ }^{13,15-18}$ focused on student and self-evaluations, whereas three ${ }^{14,17,20}$ used either an objective structured teaching examination (OSTE) or a third-party evaluation of a structured interview. Studies using both outcome measures were able to demonstrate significant improvements in the intervention vs the control group. One ${ }^{20}$ study used a survey instrument, the Clinical Teaching Perception Inventory, to assess the comfort of the residents in their teaching role. There was no effect of the intervention on this survey. Most of the articles did not include numeric data in their articles. The results are summarized in table 2 .

\section{Discussion}

The importance and prevalence of resident teaching has been established, and because of this, there is a need for effective, proven techniques to develop residents' teaching skills. As these studies reveal, however, further work needs to be done to identify the most effective methods. Notably, none of these studies included neurology residents, and neurologists need to catch up with other specialties regarding assessing our resident teaching abilities and techniques. These studies demonstrate that teaching workshops can improve resident teaching skills as measured by objective teaching examinations. The studies also suggest that the effect of student feedback may not be as great as that of teaching skills sessions. Only one of the three studies using student feedback as an intervention was able to demonstrate a significant improvement in the experimental group, whereas four of the five studies using skills sessions were able to demonstrate a significant improvements in the experimental group.

With the current goal of the ACGME to promote verifiable outcomes of residency training via the core competencies, it is important to highlight the studies that employed validated and reliable outcome measures. The earliest study to do this was by Edwards, ${ }^{14}$ which employed a standardized evaluation by trained psychology students of videotaped interactions of residents and students. This outcome measure was unique to this study and predated the OSTE used in later studies. The OSTE is an observed examination that has been validated for evaluating the teaching skills of faculty. When modified for use by residents, the OSTE remains a reliable and valid evaluation technique. ${ }^{21}$ It involves observing residents' interactions with medical students along several stations to test the important teaching skills needed by residents. The studies by Dunnington $^{17}$ and Morrison ${ }^{20}$ used 
Table 1 Summary of studies

\begin{tabular}{|c|c|c|c|c|}
\hline Study & Jewett ${ }^{13}$ & Edwards $^{14}$ & Bing-You ${ }^{15}$ & Litzelman $^{16}$ \\
\hline Year & 1982 & 1988 & 1997 & 1998 \\
\hline Sample size & 55 & 12 & 28 & 39 \\
\hline Type of residents & Ped & IM, FM, OB/GYN & IM, Ped & IM \\
\hline Intervention & $\begin{array}{l}\text { Two } 1 / 2 \text { day workshops } \\
\text { with follow-up } \\
\text { feedback sessions }\end{array}$ & $\begin{array}{l}\text { One } 1 / 2 \text { day workshops } \\
\text { with follow-up } \\
\text { videotaped session }\end{array}$ & $\begin{array}{l}\text { Written summary of student } \\
\text { feedback }\end{array}$ & $\begin{array}{l}\text { Summarized student } \\
\text { feedback during } \\
\text { ward months }\end{array}$ \\
\hline Outcome measures & $\begin{array}{l}\text { Student, faculty, peer, } \\
\text { and self evaluations }\end{array}$ & $\begin{array}{l}\text { Trained rater } \\
\text { evaluations of } \\
\text { videotape }\end{array}$ & $\begin{array}{l}\text { Trained researcher } \\
\text { interview of medical } \\
\text { students/junior residents, } \\
\text { CTAF }\end{array}$ & $\begin{array}{l}\text { Student and self- } \\
\text { evaluations }\end{array}$ \\
\hline Findings & $\begin{array}{l}\text { No significant effect on } \\
\text { student ratings, but } \\
\text { self ratings showed } \\
\text { greater confidence in } \\
\text { teaching ability }\end{array}$ & $\begin{array}{l}\text { Small, but significant } \\
\text { improvement in } \\
\text { overall teaching } \\
\text { rating }\end{array}$ & $\begin{array}{l}\text { Small, but significant } \\
\text { improvement on two } \\
\text { sections of CTAF, no } \\
\text { significant improvement } \\
\text { in overall teaching rating }\end{array}$ & $\begin{array}{c}\text { No significant effect } \\
\text { of intervention }\end{array}$ \\
\hline
\end{tabular}

Ped = pediatrics; IM = internal medicine; FM = family medicine; OB/GYN = obstetrics and gynecology; OSTE = objective structured teaching examination; CTAF $=$ Clinical Teaching Assessment Form; CTPI = Clinical Teaching Perception Inventory.

the OSTE, a standardized outcome measure, to evaluate observed resident performances and show that their teaching curricula was effective. Because of its standardization and validation, the OSTE should be employed in future studies of teaching methods for residents. The ultimate goal, though, should be to employ a measure of student learning, as this is ultimately the outcome of greatest importance. Presently, there are no published studies that have used this as an outcome.

The studies in this review also do not address the optimal curricu- lum for teaching residents or if the combination of skills sessions and student feedback is synergistic. A common theme in several of the workshops was the five microskills technique, used by Morrison, ${ }^{20}$ Dunnington ${ }^{17}$ and Furney. ${ }^{18}$ This technique has been used by faculty to teach residents and stresses the "teachable moment." 22 The five microskills that should be used whenever a opportunity to teach arises are (1) get a commitment, (2) probe for supporting evidence, (3) teach general rules, (4) reinforce what was done right, and (5) correct mis- takes. In the study by Morrison, ${ }^{20}$ the authors identified this technique along with others from their review of the literature on effective teaching methods for faculty. They then modified those methods for residents. The nature of the literature on the content of teaching curricula is beyond the scope of this article, but further information on programs that have been used across the country can be obtained on the Web site http://www.residentteachers. com. ${ }^{12}$ Dr. Morrison et al. produced this Web site as part of their ongoing study of resident teaching techniques.

Table 2 Summary of results from identified studies

\begin{tabular}{|c|c|c|c|c|}
\hline Study & Outcome & Intervention & Control & Significance \\
\hline Jewett ${ }^{13}$ & $\begin{array}{l}\text { Student, peer, and faculty } \\
\text { rating of teaching } \\
\text { effectiveness }\end{array}$ & $52 \%$ & $27 \%$ & Not significant \\
\hline Edwards $^{14}$ & $\begin{array}{l}\text { Trained rater evaluation } \\
\text { of videotaped } \\
\text { interaction }\end{array}$ & $\begin{array}{l}4.49 \pm 0.17 \\
(1 \text { to } 6 \text { scale, } 6 \text { highest })\end{array}$ & $3.49 \pm 0.22$ & $p<0.017$ \\
\hline Bing-You ${ }^{15}$ & $\begin{array}{l}\text { Student rating of overall } \\
\text { teaching effectiveness }\end{array}$ & Data not given & & $p=0.07$ \\
\hline Litzelman $^{16}$ & $\begin{array}{l}\text { Student rating of overall } \\
\text { teaching effectiveness }\end{array}$ & Data not given & & Not significant \\
\hline Dunnington $^{17}$ & OSTE & Overall teaching quality not measured & & N/A \\
\hline Furney $^{18}$ & $\begin{array}{l}\text { Student rating of overall } \\
\text { teaching effectiveness }\end{array}$ & $\begin{array}{l}4.07 \\
\text { ( } 1 \text { to } 5 \text { scale, } 5 \text { highest) }\end{array}$ & 4.00 & Not significant \\
\hline Mass $^{19}$ & $\begin{array}{l}\text { Student rating of overall } \\
\text { teaching }\end{array}$ & Data not given & & Not significant \\
\hline Morrison $^{20}$ & Grand mean OSTE score & $\begin{array}{l}3.46 \pm 0.26 \\
(1 \text { to } 5 \text { scale, } 5 \text { highest })\end{array}$ & $2.66 \pm 0.16$ & $p<0.005$ \\
\hline
\end{tabular}

OSTE $=$ objective structured teaching examination; N/A $=$ not available. 


\begin{tabular}{|c|c|c|c|}
\hline Dunnington $^{17}$ & Furney ${ }^{18}$ & $\operatorname{Mass}^{19}$ & Morrison $^{20}$ \\
\hline 1998 & 2001 & 2001 & 2003 \\
\hline 62 & 57 & 22 & 23 \\
\hline Surgery & IM & OB/GYN & IM, FM, Ped \\
\hline $\begin{array}{l}\text { Weekend skills retreat } \\
\text { of five microskills }\end{array}$ & $\begin{array}{l}\text { 1-hour session teaching } \\
\text { 1-minute preceptor }\end{array}$ & $\begin{array}{l}\text { Written vs oral student } \\
\text { feedback }\end{array}$ & $\begin{array}{l}\text { Pre/Post test OSTE, 13-hour } \\
\text { teaching curriculum }\end{array}$ \\
\hline OSTE & $\begin{array}{l}\text { Student and self } \\
\text { evaluations }\end{array}$ & $\begin{array}{l}\text { Student and self } \\
\text { evaluations }\end{array}$ & OSTE, CTPI \\
\hline $\begin{array}{l}\text { Significant } \\
\text { improvement in } \\
\text { several stations of } \\
\text { OSTE by } \\
\text { intervention group }\end{array}$ & $\begin{array}{l}\text { Significant increase } \\
\text { rating by students in } \\
\text { all microskills, but } \\
\text { not overall teaching } \\
\text { ability }\end{array}$ & $\begin{array}{l}\text { No significant effect of } \\
\text { intervention }\end{array}$ & $\begin{array}{l}\text { Significant improvement by } \\
\text { intervention group on } \\
\text { many sections of OSTE; no } \\
\text { effect on CTPI }\end{array}$ \\
\hline
\end{tabular}

Generalizing these findings to neurology is problematic. These studies do not address the specific needs of neurology residents, i.e., that neurology employs unique physical examination techniques, as well as complex neuroradiologic and neurophysiologic studies. All of these are difficult to master, especially for junior residents and are intimidating to teach to medical students. These and other teaching challenges for neurology residents have been detailed by Gelb ${ }^{23}$ and Frank. ${ }^{24}$ Dr. Gelb has pioneered the use of computer-aided neuroanatomical teaching aides for neuroanatomy as an adjunct to the teaching done on the wards by residents. Dr. Frank discusses the use of bedside and small group teaching techniques that can be used by neurology residents. Techniques such as these may be beneficial, but need to be critically evaluated. These and other methods could be used as part of a larger teaching curriculum specific for neurology. Any study should use validated standardized outcome measures, i.e., an OSTE, as well as outcome measures of student learning.

In order to accomplish the goal of improving resident teaching in neurology, there needs to be community-wide commitment to improving this aspect of residency. This dedication needs to be in the form of funding and recognition that research in this field is vital for neurology departments and the future of neurologists. Residents and fellows need to involve themselves as future faculty to participate in the improvement of teaching methods. We need to prove that those who can, teach.

\section{Conclusions}

The quantity of teaching done by residents is substantial, but the quality and impact needs further study. The number of rigorous studies on techniques to improve the teaching done by residents is small. The studies that do exist suggest that a curriculum including workshops on teaching skills for residents can improve the residents' teaching ability as measured by an OSTE. Further studies, especially those that involve neurology residents and fellows, the future faculty in neurology, are needed.

\section{References}

1. Lapalio LR. Time study of students and house staff on a university medical service. J. Med Educ. 1981;56:61-64.

2. Brown RS. House staff attitudes toward teaching. J Med Educ 1970;45: 156-159.

3. Core Curriculum Working Group, Group on Educational Affairs/Section for Graduate Medical Education, Group on Resident Affairs, Organization of Resident Representatives. Graduate medical education core curriculum. Washington, D.C.: Association of American Medical Colleges, 2000.
4. Pelletier M, Belliveau P. Role of surgical residents in undergraduate surgical education. Can J Surg 1999;42: 451-456.

5. Accreditation Council for Graduate Medical Education. Program requirements for residency education in neurology. (http://www.acgme.org/downloads/ RRC_progReq/180pr202.pdf). Accessed 3/16/04. Accreditation Council for Graduate Medical Education, Chicago, IL 2002.

6. Morrison, EH Friedland JA, Boker J, Rucker L, Hollingshead J, Murata P. Residents-as-teachers: training in U.S. residency programs and offices of graduate medical education. Acad Med 2001;76(suppl):S1-S4.

7. Liaison Committee on Medical Education. Function and structure of a medical school. standards for accreditation of medical education programs leading to the m.d. degree. (http://www.lcme.org/ functions2004february.pdf). Accessed 3/18/04. Association of American Medical Colleges and American Medical Association, Washington, D.C. and Chicago, IL, 2004.

8. Charles PD, Scherokman B, Jozefowicz RF. How much neurology should a medical student learn? a position statement of the aan undergraduate education subcommittee. Acad Med 1999;74:23-26.

9. Smith AG, Bromberg MB, Singleton JR, Forshew DA. The use of "clinic room" presentation as an educational tool in the ambulatory care setting. Neurology 1999;52:317-320.

10. Heckman JG, Bleh C, Dütsch M, Lang CJG, Neundörfer B. Does improved problem-based teaching influence students' knowledge at the end of their neurology elective? an observational study of 40 students. J Neurol 2003; 250:1464-1468.

11. Gelb DJ, Gunderson CH, Henry KA, Kirshner HS, Jozefowicz RF. The neurology clerkship core curriculum. Neurology $2002 ; 58: 849-852$. 
12. Morrison E, Friedland JA, Hitchcock M, Boker J, Garman K, Rucker L, Hafler JP. Residents' teaching skills web site. (http://www.residentteachers. com). Accessed 5/12/04.

13. Jewett LS, Greenberg LW, Goldberg RM. Teaching residents how to teach: a one-year study. J Med Educ 1982;57: 361-366.

14. Edwards JC, Kissling GE, Brannan JR, Plauché WC, Marier RL. Study of teaching residents how to teach. J Med Educ 1988;63:603-610.

15. Bing-You RG, Greenberg LW, Wiederman BL, Smith CS. A randomized multicenter trial to improve resident teaching with written feedback. Teach Learn Med 1997;9:10-13.

16. Litzelman DK, Stratos GA, Marriott DJ, Lazaridis EN, Skeff KM. Beneficial and harmful effects of augmented feedback on physicians' clinicalteaching performances. Acad Med 1998;73:324-332.

17. Dunnington GL, DaRosa D. A prospective randomized trial of a residentsas-teachers training program. 73:696700, 1998

18. Furney SL, Orsini AN, Orsetti KE, Stern DT, Gruppen LD, Irby DM. Teaching the one-minute preceptor a randomized controlled trial. J Gen Intern Med 2001;16:620-624.

19. Mass S, Shah SS, Daly SX, Sultana CJ. Effect of feedback on obstetrics and gynecology residents' teaching performance and attitudes. J Reprod Med 2001;46:699-674.

20. Morrison EH, Rucker L, Boker JR, et al. A pilot randomized, controlled trial of a longitudinal residents-as-teachers
Curriculum. Acad Med 2003;78:722729 .

21. Morrison EH, Boker JR, Hollingshead J, Prislin MD, Hitchcock MA, Litzleman, DK. Reliability and validity of an objective structured teaching examination for generalist resident teachers. Acad Med. 2002;77(suppl): S29-S32.

22. Neher JO, Gordon KC, Meyer B, Stevens N. A five-step "microskills" model of clinical teaching. J Am Board Fan Pract 1992;5:445-450.

23. Gelb DJ. Where's the logic in neurologic education? Exp Neurol 2003; 184(Suppl 1):S48-52.

24. Frank, SA Jozefowicz RF. The challenges of residents teaching neurology. Neurologist. 2004 Jul;10:216220 . 


\title{
Neurology
}

\author{
The neurology resident as teacher: Evaluating and improving our role \\ David J. Gill and Samuel A. Frank \\ Neurology 2004;63;1334-1338 \\ DOI 10.1212/01.WNL.0000140255.63532.28
}

This information is current as of October 11, 2004

Updated Information \& Services

References

Citations

Permissions \& Licensing

Reprints including high resolution figures, can be found at: http://n.neurology.org/content/63/7/1334.full

This article cites 17 articles, 2 of which you can access for free at: http://n.neurology.org/content/63/7/1334.full\#ref-list-1

This article has been cited by 1 HighWire-hosted articles: http://n.neurology.org/content/63/7/1334.full\#\#otherarticles

Information about reproducing this article in parts (figures,tables) or in its entirety can be found online at:

http://www.neurology.org/about/about_the_journal\#permissions

Information about ordering reprints can be found online:

http://n.neurology.org/subscribers/advertise

Neurology ${ }^{\circledR}$ is the official journal of the American Academy of Neurology. Published continuously since 1951, it is now a weekly with 48 issues per year. Copyright. All rights reserved. Print ISSN: 0028-3878. Online ISSN: 1526-632X.

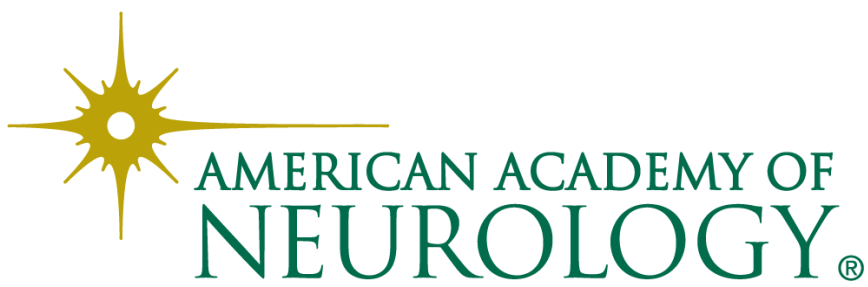

